\title{
ČLÁNKY
}

\section{Poznámky ke stavu oboru ústavního práva a státovědy*}

\section{Considerations on Condition of Constitutional Law and Theory of State}

\author{
Jan Kysela ${ }^{* *}$
}

\begin{abstract}
Abstrakt
Článek, je prüspèvkem ke vymezování branic a stavu oboru ústavního práva a státovědy. Nastinùje míru propojeni ústavního práva a politiky, jež. má dopady na metodologii prǐstupu k ústavnimu právu. Dále poukazuje na dvě tradični části ústavníbo práva, organickou a lidskoprávni, a upozorñuje jednak na promèny jejich pomèru, jednak na zvyšujicí se míru konstitucionalizace společenských vatabio a jeji dopady. V posledni cásti poukazuje na typická témata současné nauky ústavního práva a podrobněji se vénuje lidským práviom (begemonie) a soudiom (dalekosáblá judicializace).
\end{abstract}

Klíčová slova

Ústavni právo; diskrece; konstitucionalizace; hegemonie lidských práv.

\begin{abstract}
The article contributes to the delimitation of the reach and state of the discipline of constitutional law and theory of state (Staatslehre). The author outlines the intensity of interconnections between constitutional law and politics, which influences the methodological approach to constitutional law. He also points to two traditional parts of constitutional law, the organic one and the other connected to the buman rights, and draws attention to the growing constitutionalization of social relations and its impacts. In the last part the author refers to the representative issues of contemporary constitutional law discipline and focuses in detail on buman rights (hegemony) and courts (far-reaching judicialization).
\end{abstract}

\section{Keywords}

Constitutional Law; Discretion; Constitutionalization; Hegemony of Human Rights.

\footnotetext{
* Článek vznikl v rámci řešení grantu GA ČR č. 17-08176S. Za jeho kritické přečtení děkuji T. Friedelovi a J. Ondřejkové.

** Prof. JUDr. Jan Kysela, Ph.D., DSc., Katedra politologie a sociologie, Právnická fakulta, Univerzita Karlova, Praha; Kancelár Senátu Parlamentu ČR / Department of Politology and Sociology, Faculty of Law, Charles University, Prague, Czech Republic; Senate Chancellery of the Parliament of the Czech Republic / E-mail: kyselaj@prf.cuni.cz / ORCID: 0000-0001-6034-628X
} 


\section{Úvod}

Před dvaceti lety jsem si v časopisu Právny obzor přečetl zajímavý článek J. Sváka „Parlamentné výsady v systéme common law a u nás", jehož název byl doplněn slovy „Tézy habilitačnej prednášky". ${ }^{1}$ Ve jmenovaném časopise jde v publikování tohoto typu textů o zavedenou praxi, kterou považuji za št’astnou: odborná veřejnost může sledovat, kdo a s jakými (a jak pojatými) tématy kvalifikačně stoupá či roste. Pod vlivem tohoto dojmu jsem později postupoval podobně i já se svou habilitační přednáškou. ${ }^{2}$

Jelikož se t. č. uzavřela jakási pomyslná etapa mého vztahu k ústavnímu právu, nebude snad považováno za projev nadměrné marnivosti, když sepíšu článek opírající se o dvojici přednášek „profesorských“, přednesených před vědeckými radami fakulty a univerzity, článek nutně omezený tím, že přednášky mají být spíše nástinem než řešením případných problémů daného oboru. ${ }^{3} \mathrm{Z}$ toho důvodu jsou i citace literatury více nahodilé než systematické.

Časopis pro právní vědu a praxi jsem k tomu účelu zvolil proto, že můj první větší článek vyšel právě v něm. ${ }^{4}$ A to zase souviselo s mimořádnou osobností prof. J. Filipa, mentora mých různých kvalifikačních řízení, mého odborného vzoru, tehdy i dnes předsedy redakční rady, jenž mne k publikaci povzbudil, resp. mi v ní nebránil. Časopis mám rád dodnes, po určitou dobu jsem ostatně psal primárně pro něj. Počítám-li dobře, čítá to 17 článků a 17 recenzí.

\section{1 Ústavní právo jako právo politiky}

O ústavním právu se občas mluvívá jako o právu politiky, slavný izraelský konstitucionalista R. Hirschl jej dokonce - v narážce na Clausewitzův výrok o vztahu války a politiky označil za formu politiky jinými prostředky. ${ }^{5}$ Moc jako atribut politiky je v hávu práva jakoby mocí (z)krocenou, kultivovanou, předvídatelnou a kontrolovatelnou. Záleží nicméně na míre pohlcení politiky právem, případně naopak na míře služebnosti ústavního práva vůči momentálním držitelům moci a jimi formulovaným partikulárním účelům a zájmům (srov. např. sémantickou ústavu K. Loewensteina).

1 Právny obzor, roč. 1997, č. 2. V mírně pozměněné podobě vyšel článek už dříve - viz SVÁK, J. Parlamentné výsady v britskom systéme Common law: porovnávací prehl'ad. Právník, roč. 1996, č. 1.

2 Parlamenty a jejich funkce v 21. století: uvedení do tématu. In: KYSELA, J. (ed.). Parlamenty a jejich funkece v 21. století. Sborník príspèvkiu k 10. výroči ustaveni Senátu Parlamentu Ceské republiky. Praha: Eurolex Bohemia, 2006.

3 Tematicky se zčásti překrývá s mou knihou Ústava meẓi právem a politikou. Úvod do ústavní teorie. Praha: Leges, 2014.

4 Dotváření Ústavy ze senátní perspektivy. Casopis pro právní vědu a praxi, roč. 2000, č. 2.

5 HIRSCHL, R. The New Constitutionalism and the Judicialization of Pure Politics Worldwide. Fordham Law Review, roč. 2006, s. 723. 
Abychom potlačili instrumentální charakter práva, mluvíváme o něm jako o (neosobním) řádu, ač samozřejmě nástrojem svého druhu je. Je nástrojem spoluzajišt’ujícím pokojné soužití lidí v určitém společenství, zachování a rozvoj tohoto společenství, a to včetně vymezení jeho hranic („,my“ a „oni“). Ve vymezení společenství jako prostoru důvěry, solidarity a elementárního konsensu sehrává významnou roli ústava (ústavní patriotismus), a to zvláště ta, jež odpovídá zásadám a hodnotám konstitucionalismu, tedy omezuje moc. Díky tomu tlumí tendenci proměňovat jinakost v nepřátelství jako charakteristický znak politična coby předpokladu politiky, státu i práva, které nicméně tak jako tak vycházejí z očekávání angažmá pro něco i proti něčemu. ${ }^{6}$ Tlumení však neznamená eliminaci, ale právě „jen“ odsunutí mimo běžné poměry. Ani to není málo.

Ústavní právo vytváří rámec, v němž se odehrávají politické procesy (politics), a to mezi vesměs jím regulovanými aktéry různého typu (polity), a k otázkám, jež považuje za př́ipustné (policy). A jako každé jiné právo je i to ústavní výsledkem politiky, politických představ, střetů i hlasování, možná jen v míře o něco vyšší. Dáno je to jak tím, že na některé ústavněprávní otázky typu prrímé volby hlavy státu mají politici častěji názor než na subtilní instituty civilního procesu, tak i tím, že každý regulovaný se zajímá především o regulaci, jež na něj dopadá. $V$ př́padě politiků je to právě ústavní právo.

V této souvislosti je sice míněno ústavní právo jako soubor pravidel vytvářených ústavodárnou či zákonodárnou mocí (ústavodárné shromáždění, parlament, referendum), evidentní však je, že k němu patří rovněž pravidla (re)formulovaná mocí soudní. Otázkou je, zda jsou kvưli tomu vyňata z politického střetu. Nějaký střet o právo je tu vždy, musí však být politický? Rozdíl bude v modelech ústavního soudnictví (všeobecný difusní versus specializovaný koncentrovaný) s dopadem na aktivní legitimaci (skupina poslanců prolongujících spor s parlamentní většinou versus občan), ale také ve sledovaných cílech. Občanovi v podmínkách něčeho na způsob actio popularis může jít o holé přečtení ústavy a její konfrontaci se zákonem, také se však může snažit přimět ústavní soud, aby v ústavě „nalezl“ něco, co tam dosud málokdo viděl, což bývá typické pro tzv. strategické litigace. Vytvoření nového pravidla je výkonem spíše politickým než aplikačním, a to bez ohledu na to, zda je tvưrce vybaven atributy ,apolitičnosti““.7 Méně jde o ony atributy, více o to, co daný orgán skutečně dělá, případně ve vztahu k jakému tématu to dělá (doktrína politické otázky ${ }^{8}$ - viz dále).

6 SCHMITT, C. Pojem politična. Brno - Praha: OIKOYMENH, 2007.

7 U nás doporučuje očistu politiky mj. omezením agendy vyhrazené k rozhodování politikům ve prospěch různých nezávislých orgánů M. Klíma. Viz KLÍMA, M. Od totality k defektni demokracii. Praha: SLON, 2015, s. 282 násl. K britské diskusi o odlišení špatné (stranické, klientelistické...) politiky a politiky jako takové viz OLIVER, D. The Politics-Free Dimension to the UK Constitution. In: QVORTRUP, M. (ed.). The British Constitution: Continuity and Change. A Festschrift for Vernon Bogdanor. Oxford and Portland, Oregon: Hart Publishing, 2013.

8 K tomu např. TOMOSZEK, M. Aplikace doktríny politických otázek Ústavním soudem ČR. In: HAMUL’ÁK, O. (ed.). Fenomén judikatury v právu. Praha: Leges, 2010; PÍČOVÁ, L. Politická otázka v judikatuře Ústavního soudu ČR. Byla, je a bude? Časopis pro právni vědu a praxi, roč. 2014, č. 2. 
Vedle pragmaticky chápaného zájmu politiků prosakuje do ústavního práva okolí (vnějšî prostředî) též v souvislostech antropologických či ideologických. Stanovování pravidel dobré vlády je nutně propojeno s tím, jak vnímáme obraz člověka, lidskou přirozenost, což můžeme pozorovat u Aristotela, Machiavelliho, Hobbese, Rousseaua, Madisona... Je vláda dobrem korigujícím to zlé (př́liš racionální, iracionální...) v člověku, anebo je spíše zlem utlačujícím přirozenou lidskou svobodu, kreativitu a autenticitu? $\mathrm{Na}$ to se samozřejmě odpovědi různí. A velmi podobné je to s ideologiemi: bez ohledu na to, jaký člověk je, můžeme mít různé názory na to, jaký být má, k jakému cíli se má vyvíjet svět, jakou roli v tom může sehrát politická moc a právo určitého státu. Vadí-li nám pejorativně znějící pojem ,ideologie“, který implikuje uzavřenost, dogmatismus či nepochybující odpovědi na vše, můžeme jej do určité míry nahradit neutrálně znějícími hodnotovými představami, jež podbarvují politickou soutěž a do různých právních odvětví se promítají s měnlivou intenzitou.

Zřejmě nejvýraznějším prŕkladem propojování ústavního práva a politiky jsou ústavní konvence, jež ostatně kanadský autor A. Heard přímo váže na „manželství práva a politiky“ $\cdot{ }^{10}$ Ústavní konvence nevznikají formalizovaným postupem jako právní pravidla, nýbrž praxí ústavních aktérů. Jejich motivem je pocit správnosti, tedy pocit, že se má postupovat právě takto, jelikož se tak postupovalo i v minulosti, případně tomu navíc svědčí nějaký principiální důvod. Konvence přispívají k vytváření a aplikování práva jako smysluplného a co možná předvídatelného celku. Podobají se právním (ústavním) obyčejům, k jejich vzniku však není třeba skutečně dlouhé doby stabilizace a také nejsou pramenem práva, tj. nerozhodují podle nich soudy. $V$ tom je patrné obecnější odlišení právních pravidel a sociálních konvencí co do sankce v př́padě jejich porušení: formalizované rúzení versus společenský odsudek, odtažitost okolí apod. V judikatuře se nicméně na ústavní konvence přesto objevují odkazy, protože jejich pomocí lze jasněji určit, co jako právo platí, jak je třeba vykládat neurčité pojmy, jak zužovat původně širokou diskreci. Jde vlastně o ustálenou praxi, jež možná nahodile začala, nenahodile však pokračovala. Častokráte se ostatně i v jiných oborech práva užívá obrazu o svalovém obalu kostry právních předpisů, kdy svalovým obalem může být jak judikatura, tak právě ustálená praxe. ${ }^{11}$

9 Srov. WINTR, J. Vliv politických idejí a programů na české zákonodárství v letech 1989-1998. In: GERLOCH, A. a P. MARŠÁLEK (eds.). Zákon v kontinentálním právu. Praha: Eurolex Bohemia, 2005, s. $293-341$.

10 HEARD, A. Canadian Constitutional Conventions. The Marriage of Law and Politics. Toronto: Oxford University Press, 1991. Klasickou knihou rozpracovávající původní členění ústavního práva v širším smyslu A. V. Diceyho nicméně je MARSHALL, G. Constitutional Conventions: the Rules and Forms of Political Accountability. Oxford - New York: Oxford University Press, 2001, původně z roku 1984.

11 Obdobně „Nontextual Instruments“ podle ELKINS, Z., T. GINSBURG a J. MELTON. The Endurance of National Constitutions. New York: Cambridge University Press, 2009, s. 45. Odlišení judikatury a praxe je podstatné, protože současná uhranutost soudy upozad'uje fakt, že se ke slovu dostávají jen v případě sporu neřešeného jinými prostředky. Ústava (nejen ona) však může být ustalována či dotvářena praxí rovněž jiných orgánů, jež jí mohou rozumět stejně dobře (lépe, hůře) než soudy. Tomu byl ostatně věnován můj první větší článek, zmíněný shora. 
Byla-li řeč o diskreci, otevírá se další pole prolínání i odlišování práva a politiky. Tím je otázka míry naprogramovanosti politiky právem. V klasickém rozlišení je s politikou spojena kreativita, invence, volnost, zatímco s právem subsumpce skutkových dějů předem danému právnímu pravidlu. Takto je postaven rozdíl gubernacula a jurisdictia u H. de Bractona, prerogativy a vykonávání zákonů u J. Locka, politiky a administrování u K. Mannheima, právní politiky a adjudikace u B. Tomsy apod. V tomto ohledu platí, že čím více je právní regulace, tím menší je prostor pro politiku v jiné podobě, než je snaha o změnu právní regulace. Politik je tím pádem bud’ zákonodárcem tvořícím pravidla, nebo úředníkem je aplikujícím. Ledaže by právní pravidla ponechávala orgánům aplikace práva tak široké prostory uvážení, že se uvnitř práva mění paradigma subsumpce ve volnost. Jenže vývoj právního státu s sebou nese omezování volnosti správy. Když ne ze strany zákonodárce, tak ze strany soudů, které zdánlivě širokou diskreci zúží. Je-li tedy řeč o ideologii volné aplikace práva, nemyslí se na úřady, nýbrž na soudy. ${ }^{12}$

A netýká se to jen správy. Vezměme jen v potaz zdejší debaty vztažené k prezidentu republiky obecně a k jeho kompetenci udělovat amnestii či milosti různého druhu zvláště. Vadit nám může, $\mathrm{k}$ jakému účelu prezident republiky svých kompetencí užívá, anebo jakým způsobem to činí. Zatímco druhý případ může souviset s kompetenční expanzí, případně kompetenčními excesy, a je možné jej nejen kritizovat, nýbrž také právními prostředky potlačovat, ten první bude více vázán na (př́pustnou?) diskreci. Máme říci, že jelikož se nám nelíbí, jak prezident republiky rozhodl, že tak rozhodnout nesměl, protože podle našeho soudu směl sledovat pouze ústavně aprobované účely, což jsou shodou okolností ty, které ctíme my? Pokud by tomu tak bylo, logicky se nabízí soudní přezkum naplňování oněch účelů, takže nakonec to bude Ústavní soud, který např. řekne, zda amnestie či milost mohla být udělena. Anebo se můžeme smírit s tím, že diskrece může být užita lecjak, přičemž sankcí může být prohra v dalších volbách, veřejné opovržení či věčné zatracení. To by asi více odpovídalo Lockově pozici ve vztahu k prerogativě, jež je limitována veřejným prospěchem a zájmem: to, co bude dovoleno jednomu knížeti, nebude dovoleno jinému, protože podstatná není kompetence, nýbrž její využití, tedy konání dobra či zla. ${ }^{13}$ Anebo můžeme dumat nad podobou relevantní právní úpravy a pokoušet se promyslet pojistky nežádoucího využívání kompetencí.

To posledně zmíněné doporučil pro určité situace ve svém vystoupení na letošních Weyrových dnech právní teorie $\mathrm{M}$. Antoš, když varoval před ústavním či ústavněprávním kýčem. Jeho podstatou jsou stížnosti na jednání konkrétních ústavních aktérů bez bližšího vyhodnocení toho, nakolik je toto jednání umožněno ústavními pravidly, a s apriorním odmítnutím bavit se o podobě či změně těchto pravidel. Ve výsledku zůstává pocit, že Ústava

12 WRÓBLEWSKI, J. The Judicial Application of Law. Dordrecht: Kluwer Academic Publishers, 2010. V češtině k tomu opakovaně publikoval Z. Kühn, viz např. KÜHN, Z. Aplikace práva ve složitých prípadech: ke úlože právnich principu v judikature. Praha: Karolinum, 2002.

13 LOCKE, J. Drubé pojednání o vládě. 2. vyd. Praha: Svoboda, 1992, s. 128-129. 
je dobrá, lidé jsou špatní, pročež musíme hledat lepší (platónská linie politického myšlenî). Vyvolává-li však určitá úprava problémy dlouhodobě, a bez ohledu na změnu personálního substrátu ústavních orgánů, není na místě zaměřit se spíše na její změnu, než na očekávání, že konečně príjde ten, který jí bude rozumět? Zhruba takto se ptal M. Antoš.

Jeho vystoupení samozřjejmě nemělo znamenat, že máme každou nespokojenost s výkonem ústavního aktéra proměnit ve změnu ústavního pravidla, které se stejně samo neprosadí, spíše bylo apelem, abychom změnu ústavního pravidla nevylučovali. Jinak vlastně s odvolávkou na respekt $\mathrm{k}$ ústavě snižujeme její vážnost, umožňuje-li tolik různých výkladů a postupů, vesměs bez sankce při zvolení toho „nesprávného““ ${ }^{14}$ Ústava je jistě dokumentem politickým, také však nepochybně právním, resp. toho času v pořadí spíše obráceném. A právě v obhajobě ústavních pravidel jako právních se M. Antoš shoduje s A. V. Diceyem. ${ }^{15}$ Dicey totiž nezavedl rozlišení ústavního práva v užším smyslu a ústavních konvencí, aby ústavu rozmlžil, nýbrž naopak. Chtěl zachránit ústavní právo v podobě pravidel vynucovaných soudy, pročež z něj vydělil ústavní morálku či politickou etiku, tedy konvence. ${ }^{16}$ Stejně tak i M. Antoš připomíná, že při výkladu Ústavy nejde jen o to, co by se mělo nebo slušelo, ale i o to, co se musí, případně nesmí. Po vzoru Hume-Jörgensenovy teze, prezentované u nás P. Holländerem, ${ }^{17}$ bychom tuto tezi mohli označit jako Dicey-Antošovu. Jinou věcí je, zda nezakázané jednání má být zcela přenecháno úradku držitele kompetence, anebo může být usměrňováno poukazy na různé typy standardů, zavedenou praxi apod. Takové usměrňování však může vycházet $z$ doktríny či veřejnosti, ne nutně od soudư. ${ }^{18}$ Jinými slovy diskrece nerovná se svévoli, z čehož bez dalšího nevyplývá nic o povaze relevantních sankcí. ${ }^{19}$

Platí-li postulát o propojení ústavního práva a politiky, není překvapivé, má-li důsledky pro metodologickou orientaci oboru. $\mathrm{V}$ minulosti u nás o tom probíhaly debaty

14 Značný rozptyl interpretace toho, co naše Ústava připouští, považuje za její výrazný deficit MALENOVSKÝ, J. O legitimitě a výkladu české ústavy na konci století existence moderního českého státu. Prámík, roč. 2013, č. 8.

15 DICEY, A. V. The Introduction to the Study of the Law of the Constitution. Indianapolis: Liberty Fund, 1982 (reprint 8. vyd. z roku 1915).

16 MARSHALL, G. Constitutional Theory. Oxford: Oxford University Press, 1971 (reprint 2011), s. 7.

17 HOLLÄNDER, P. Filosofie práva. 2. vyd. Plzeň: Aleš Čeněk, 2012.

18 Patrně se tu dají rozlišit tři př́stupy. Podle prvního, odpovídajícího pozici P. Labanda v 19. století, dosahuje ústavní právo pouze někam, ponechává tedy určité jevy, procesy a situace neupravené. Druhý př́istup pracuje $\mathrm{s}$ tím, že právo je $\mathrm{v}$ zásadě všude, vytváři však ve svém rámci něco jako bubliny, a to právě $\mathrm{v}$ podobě diskrece. Ta může být $\mathrm{v}$ určitých mezích ničím nepodmíněná, anebo by její výkon mohl být podřízen obecným principům a mimoprávním měřítkủm hodnocení. Př́stup třetí podřizuje vše relativně konkrétním vodítkům s možností přezkumu.

19 Zřejmě něčemu takovému říká M. Jestaedt po vzoru H. Krügera „,ústavní očekávání: jde o ústavou vyžadovanou pozici, jež odpovídá správnosti - obrazu obecného blaha, aniž by přitom byla svázána právní sankcí. Viz JESTAEDT, M. Die Verfassung binter der Verfassung. Eine Standortsbestimmung der Verfassungstheorie. Paderborn - München - Wien - Zürich: Ferdinand Schöningh, 2009, s. 61. 
v 60. letech na stránkách Právníka, po roce 1989 spíše v denním tisku. K větší otevřenosti vědy ústavního práva se hlásili V. Klokočka, P. Peška nebo J. Blahož. Podobné debaty probíhaly a probíhají rovněž v zahraničí. Známá je metodologická tenze poznamenávající pěstování ústavního práva ve výmarském Německu, různé prístupy však vidíme i v angloamerickém světě či ve Francii: organické ústavní právo se pěstuje se znalostí politických procesů a institucí. Nemá to samozřejmě znamenat úplnou metodologickou rozbředlost, pročež je účelné odlišovat vědu ústavního práva jako ústavní dogmatiku (pravidla s určitým předmětem) a širší ústavní teorii, do níž mohou pronikat filosofické, politologické a sociologické komponenty (metapravidla, teorie interpretace, metajuristické pojmy, modely, principy, předporozuměnî). ${ }^{20}$ Jistě ne vše, co projevuje zájem o ústavu jako řád vládnutí dané společnosti, je ústavním právem, jistě ne každý zájemce je konstitucionalistou. $\mathrm{Na}$ druhou stranu nemůže být věda ústavního práva hermeticky uzavřenou, nemá-li se stát slepou, ${ }^{21}$ tj. trpně prijímající jakoukoli ústavní úpravu nahlíženou výlučně prostředky jazykového výkladu. Znamenalo by to mj. rezignaci na analýzu původu a účelu daných pravidel (různé druhy komparace), také však vyloučení právněpolitických úvah, které na základě znalosti regulovaných vztahů umožňují promýšlet př́padnou lepší regulaci.

Relevantní je tu pripomenutí Ch. Perelmana: „Právni systém totiž neni uzavrený a izolovaný od svébo kulturního a společenskébo kontextu, naopak, stále od nèj prijímá podnèty. "22 Či velmi podobná slova I. Muchy, reflektující právně-sociologickou orientaci ve zkoumání práva: „Zvykyy, konvence, normy a zákony jsou zakódovány v reálném životé lidských komunit a společnosti. “23 To platí jak pro soudcovské právo, tak pro právotvorbu legislativní. Jistě z toho neplyne, že konstitucionalista by měl být sociologem či antropologem, dozajista by si však měl být vědom kontextu svého oboru. J. Reschová v této souvislosti připomíná poznámku V. Bogdanora o navázání kodifikované ústavy na předústavní a mimoústavní zdroje normativity, což se promítá jak v tom, vưči čemu se ústava vymezuje (pozitivně navazuje, negativně se vyhraňuje - reaktivní ústava), tak v její akceptaci a v předporozumění, s nímž se k ní prristupuje. ${ }^{24}$ Limituje to mj. efekt právních transplantátů, jsou-li přesazeny do kulturně cizorodého prostředí. Stejně tak to však mưže podvázat účinnost politické, historické, evoluční, zkrátka britské ústavy, když se společnost změní natolik (proměna politické třídy, kulturní a etnická heterogenita), že dříve samozřejmé kulturní a politické normy samozřejmými, resp. srozumitelnými být přestanou. To může vytvořit tlak

20 Takto odlišuje ústavněprávní a politologickou perspektivu při analýze konstitucionalismu rovněž J. Reschová. S tou první spojuje proces vzniku a změn ústav či interpretaci textu, s tou druhou vazby mezi mocemi nebo roli institucí. Viz RESCHOVÁ, J. Evropský konstitucionalismus: zdroje, formy a tendence. Praha: Vysoká škola ekonomická, 2003, s. 7.

21 JESTAEDT, M., op. cit.

22 PERELMAN, CH. Právna logika. Nová rétorika. Bratislava: Kalligram, 2014, s. 120.

23 MUCHA, I. Promény práva a společnosti. Plzeň: Aleš Čeněk, 2015, s. 130.

24 RESCHOVÁ, J., op. cit., s. 23-24. 
na zevrubnější psanou regulaci, u níž je role předporozumění přece jen o málo menší. Obdobné otazníky však lze kreslit rovněž u 230 let staré a značně obecné Ústavy americké: je-li reflexí hodnot a představ o dobré vládě, bude fungovat stejně v podmínkách převahy protestantských Anglosasů i při její absenci? ${ }^{25}$

Někdy se tak ten či onen konstitucionalista věnuje více dogmatice, jindy teorii, obor unese obojí. Připadá mi zkrátka, že je tu prostor pro více metodologických linií, jež se promítají v různě otevřené koncepci ústavního práva. Rizikem je samozřjejmě to, které bývá v USA prripomínáno u širokého metodologického zaměření „Law in Context" (Law and Economics/Politics/Society/Literature...) - že je tu tolik kontextu, až se v něm ztratí právo.

\section{2 Ústavní právo jako odvětví}

Tušíme už tedy, že ústavní právo souvisí s politikou jako činností i „hracím polem“, měli bychom však upřesnit, co jím je. Odlišit můžeme odvětví ústavního práva jakou součást systému práva, jenž je rozebírán v učebnicích teorie práva, a ústavní právo jako obor, vědu či nauku, jež se zabývá reflexí onoho odvětví. A jde o to, jak je to reflexe široká a hluboká.

Mluvíme-li o odvětví ústavního práva, jde z hlediska struktury především o právní normy (pravidla) obsažená v pramenech práva různého typu (ústava, ústavní zákony, zákony, podzákonné předpisy, mezinárodní smlouvy), ale i o rozhodnutí orgánů veřejné moci s obecnými účinky (typicky rozhodnutí ústavních soudů, př́padně jiných vysokých soudů, také však rozhodnutí jiných orgánů vyjasňující kompetence a procedury - delegace kompetence hlav států, usnesení parlamentních komor vykládající ústavu nebo jednací řády), ba i o stabilizované postupy veřejné moci, opřené o pocit správnosti v nakládání se svěřnými pravomocemi (ústavní konvence). Podstatné je samozřejmě to, čeho se týkají.

A tu se zřetelně rozvíjejí dvě základní oblasti ústavního práva, v této podobě profilované vlastně už od ústav jednotlivých severoamerických států v 18. století. Za prvé jde o organické ústavní právo (frame of government), jež pojednává o zř́izení, kompetencích, ustavení, odpovědnosti a vzájemných vztazích nejvyšších orgánů státu (horizontální úroveň),

25 To je dílčí prvek pozdního spisu S. Huntingtona Kam kéáčšs, Ameriko? Praha: Rybka Publishers, 2005. Je přiznačné, že známý francouzský filosof B.-H. Lévy ve svém svérázném cestopisu vyjadřuje z tohoto spisu a ze zatrpklého Huntingtona zklamání (hispanofobní, xenofobní...). Viz LÉVY, B.-H. Americká závrat’. Brno: Host, 2006, s. 248, 253 násl. Když to trochu zveličím, důvodem zřejmě má být, že ze změny (jakékoli?) a z pestrosti (jakékoli?) se přece máme radovat, a nikoliv v tom vidět konec. Resp. konec to možná bude, ale jednak všechno skončí, jednak třeba začne něco nového, ještě pěknějšího. Tuto linku lze ostatně sledovat i v debatě o budoucnosti moderního státu, započaté P. Holländerem a t. č. sebrané in AGHA, P. (ed.). Budoucnost státu? Praha: Academia, 2017. Důležitá je též Holländerova reakce viz HOLLÄNDER, P. Soumrak moderního státu - post scriptum. Právnické listy, roč. 2017, č. 1. Proti opojnému optimismu jistě nelze ničeho namítat (možná dělá lidi lepšími), neměl by však přerůst v kaceřování skeptiků a pesimistů jako vyvrhelů. 
potažmo o patrech systému veřejné moci, nemají-li čistě hierarchickou, jen na dělbě práce založenou povahu (vertikální úroveň ve smyslu federativního členění, autonomie nebo územní samosprávy versus dekoncentrace ústředních správních úradů). Za druhé jde o vymezení vztahů státu a jednotlivce, resp. limitů moci státu vưči jednotlivci v podobě katalogů základních práv a svobod (bill of rights). Plynutím času se žretelně proměnil význam obou částí ústavního práva, ${ }^{26}$ což je konečně vidět i na literární produkci, jež je orientována zejména na lidská práva, kazuistiku a judikaturu, a nikoliv na systém výkonu veřejné moci. O tom však ještě bude řeč.

Proměna vztahu obou částí se týká především juridizace ústav, tedy toho, že začaly být považovány za prímo aplikovatelné právo, přičemž objem sporů o základní práva jednotlivců je vcelku samozřejmě mnohonásobný ve vztahu ke sporům o rozsah kompetencí ústavních orgánů či o ústavnost právních předpisů.

Nejde však jen o to, že původní monology zákonodárce zatlačily zdůrazňováním primátu jednotlivce před státem do pozadí organické ústavní právo, které pracuje se státem jako s daností a svého druhu i s dobrem sloužícím občanům, zaměruje se současně kanalizováním a rozdělením moci na to, aby nepervertoval. Lidskoprávní katalogy totiž nejsou zdaleka jen monology zákonodárce, potažmo výrazem shody vysokých smluvních stran v mezinárodním právu, nýbrž změnily se ve shora zmíněnou kostru, která není patrná ani tak pod obalem zákonů, jako spíše soudních rozhodnutí. To, co lidská práva obnášejí, vyjevují (nalézají?) tudíž spíše soudy než ústavodárná shromáždění nebo parlamenty. Relativizována je tak teze, kdesi vyjádřená R. Dahlem, že lidská práva omezují většinu, nejdříve však většina musí stanovit, co jsou lidská práva (sebeomezenî).

Kromě proměny povahy ústavy a vzájemného vztahu obou klasických částí ústavního práva je třeba zmínit rovněž rostoucí konstitucionalizaci řady témat (společenských vztahů). Nejčastěji se na to upozorňuje na př́ikladu rozsáhlé brazilské ústavy, v našich poměrech je to patrné na politicky citlivých tzv. finančních ústavách. ${ }^{27}$ Souvisí to jak s rostoucím objemem úkolů a cîlů státu (nejen sociální stát - je-li tedy ústavní právo právem politiky, bytní v závislosti na tom, co předmětem státní politiky je: otázky ekonomické, medicínské aj.), tak zřejmě i s narůstajícím strachem z (prosté) většiny, jejímuž rozhodování (unáhlenému, iracionálnímu, necitlivému, nekompetentnímu...) se vytvářejí překážky „opevněním“ dané otázky v ústavní úpravě. Tím ovšem omezujeme to, oč je možné vést politický boj, aniž by přerůstal v potřebu změny ústavních pravidel. Vede-li se totiž politický boj o ústavní pravidla, oslabuje se tím jejich role stabilního rámce, potažmo kotvy veřejného dění.

26 Lidská práva působila v rámci politické a morální doktríny, do práva se přesunula jako specifické tolerance (M. Kriele) ze strany státu (typická náboženská tolerance), pak jako monology zákonodárce (J. Pražák), posléze jako vynutitelná práva. Dnes hrají roli trumfů, trumfových karet (R. Dworkin).

27 ŠIMÍČEK, V. (ed.). Finanční ústava. Brno: Masarykova univerzita, 2013. 
Subvariantou neurčitého strachu z libovolné většiny je velmi konkrétní strach z příští politické většiny v podmínkách systémových proměn. Stávající držitelé moci počítajî s tím, že ji ztratí, pokoušejí se však zafixovat své dědictví na ústavní úrovni, ideálně v kombinaci se zajištěním vlivu na ústavní či nejvyšší soud, který bude ústavu vykládat a chránit. ${ }^{28}$ To je podstatou tzv. pojišt'ovací teze T. Ginsburga, již lze doložit na řadě zemí Latinské Ameriky. ${ }^{29}$

\section{3 Ústavní právo jako obor: schematický nástin stavu, trendů a tendencí}

Nauka či věda ústavního práva zkoumá, promýšlí, komentuje či kritizuje právní úpravu nastíněnou výše, zabývá se však též její pojmovou strukturou, historickým a sociálním kontextem. Plynule přechází v ústavní teorii a ve státovědu, od nichž přebírá např. poznatky o typologii a trvanlivosti ústav, samotné ideji konstitucionalismu, významu a proměně rolí státu, jiných (alternativních) typech organizace politické moci, případně též o její privatizaci, apod.

Pokud jde o relevantní pojmy, může jít jak o obecné pojmy typu suverenity, tak o pojmy označující zavedené právní instituty jako je odpovědnost a její typy nebo kontrasignace. Povědomí o vzniku, vývoji a vrstevnatém významu takových pojmů umožňuje náležitě interpretovat texty, v nichž se na ně odkazuje. Texty ústav se přitom vyznačují vyšším podílem právě velmi obecných a neurčitých pojmů, programovými ustanoveními, neúplnými normami apod., jež kladou na interpretaci značné nároky. ${ }^{30}$ Zřetelný je tu též hodnotový základ, jenž by se měl v interpretaci a aplikaci ústavních pravidel projevovat. O tom už však ve vztahu k limitům diskrece byla řeč výše. Neznamená to ovšem, že cokoliv je v ústavách napsáno, je nutně neurčité, mnohovýznamové, diskursivní, věcí názoru...(viz ostatně Dicey-Antošovu tezi zmíněnou výše). ${ }^{31}$

Tak jako se během 20. století změnil poměr obou základních částí ústavního práva jako odvětví, změnila se i struktura vědy ústavního práva. Ch. Möllers ukazuje, jak se v Německu po 2. světové válce změnil převládající státovědný diskurs v ústavněprávní: místo

28 Ke vztahu míry konstitucionalizace politického systému a soudních garancí viz též RESCHOVÁ, J., op. cit., s. 159.

29 Viz např. MOUSTAFA, T. a T. GINSBURG. Introduction: The Functions of Courts in Authoritarian Politics. In: MOUSTAFA, T. a T. GINSBURG (eds.). Rule by Law. The Politics of Courts in Authoritarian Regimes. Cambridge University Press, 2008. V současnosti je ukázkovou laboratoří Venezuela, v níž autoritářský režim dokázal významně oslabit důsledky volebního vítězství opozice ve volbách do Kongresu právě za pomoci obsazení nejvyšší soudní instance.

30 Böckenfördeho paradoxem má být př́má aplikovatelnost ústav navzdory jejich neurčitosti, resp. vyšší míre otevřenosti jejich textury. Srov. např. HOLLÄNDER, P. Ústavnèprávni argumentace. Oblédnutípo deseti letech Ústavního soudu. Praha: Linde, 2003. P. Holländer na tento paradox upozorňuje i v dalších svých textech.

$31 \mathrm{~K}$ jazyku ústav (vyjádření politických kompromisů, přebírání terminologie, zastarávání apod.) srov. FILIP, J. Ústavni právo Ceské republiky. 1. Základni pojmy a instituty. Ústavní qáklady ČR. 4. vyd. Brno: Masarykova univerzita a Doplněk, 2003, s. 130-132. 
otázek vztahu práva a politiky, včetně míry imunizace politických jednání před soudním přezkumem, se stala dominantní metodologie interpretace norem, místo profesorů, jejich knih, časopisů a odborných setkání se stali klíčovými soudci a jejich rozhodnutí. Snížil se význam „,pojmově-konstruktivní vědy státního práva“, 32 pro někoho až príliš. Podle M. Jestaedta se stala judikatura Spolkového ústavního soudu náhražkou (kritické) teorie, což označuje pěkným slovem „Bundesverfassungsgerichtspositivismus“. ${ }^{33}$

Není na tom nic specificky německého. Zatímco v USA byla pozornost judikatuře vždy prioritní, což však neznamená výlučná, v Evropě tomu tak nebývalo. Koneckonců i u nás je dnes pro studenty typičtější studium soudních rozhodnutí než zákonů či dokonce literatury. Přibývá odborných textů psaných ryze prismatem judikatury (zvláště Ústavního soudu nebo Nejvyššího správního soudu), tj. bez kritického odstupu. Umocněno je to mezi akademiky rozšířenou módou soudcovský talár bud’ oblékat, nebo jiným s jeho nošením alespoň pomáhat. Problém XY není v takovém př́padě řešen článkem, ale rozsudkem, nálezem, usnesením... Patrná je též zdrženlivost ve vyjádřeních k aktuálním kauzám, protože „co kdyby skončily u nás“. Ve středu zájmu judicializovaných akademiků jsou vcelku pochopitelně témata, jimiž se v praxi primárně zabývají, tedy spíše lidskoprávní, než organická či dokonce státovědná. Těžko to někomu zazlívat, ale mělo by jít o míru. ${ }^{34}$

V posledních dekádách je evidentní, že zaměření na lidská práva je dominující (původ, typologie, účinky, katalogy, systémy ochrany, limity, kazuistika). Je s tím spojeno i to, čemu se porůznu rríká imperialismus, hegemonie, rétorika nebo politika lidských práv, debaty o právu na práva apod. Lidská práva v tomto světle fungují jako ultimátní argument

32 MÖLLERS, Ch. Der Vermisste Leviathan. Staatstheorie in der Bundesrepublik. Franfurt am Main: Suhrkmap Verlag, 2008, s. 38-40. Ústřední role profesorů státního práva v německých ústavních debatách 19. a první poloviny 20. století si všímá rovněž P. C. Caldwell: publikovali prríručky státního práva, rozpracovávali abstraktní témata, školili a dozorovali společensky vlivný stav právníků... Viz CALDWELL, P. C. Popular Sovereignty and the Crisis of German Constitutional Law. The Theory and Practice of Weimar Constitutionalism. Durham - London: Duke University Press, 1997, s. IX.

33 JESTAEDT, M., op. cit., s. 39.

34 Koneckonců mnohé z toho, co jsem kdy napsal, souviselo s mou parlamentní (senátnî) praxí. J. Přibáň upozorňuje na hledání mimoakademických kariér rovněž u německých akademiků, u nichž přitom patrně nepůjde o potřebu přivýdělku, jako spíše o potřebu různorodé seberealizace (ústavní soudci, členové legislativních rad, vládní a ministerští poradci). Do této kategorie vlastně patřím též, přesto se domnívám, že jde o jiný typ potenciální tenze než je tomu v případě souběžné celoživotní kariéry vyžadující sebeomezení. Ale možná jen nevidím břevno v oku svém. Příznačné ostatně je, že mi tento osobní přesah připomněl T. Friedel. Srov. PŘIBÁŇ, J., HVÍŽĎALA, K. Tyranižovaná spravedlnost. Praha: Portál, 2013, s. 187. Bezproblémový nemusí být ani souběh činnosti právního akademika s výkonem advokacie - srov. RICHTER, T. Koho chleba jíš, toho píseň zpívej. Konflikty vznikající při propojení právní praxe s právní teorií. Právník, roč. 2013, č. 2. Vysvětlení T. Richtera, proč k takovému souběhu dochází, mírí primárně k výši př́immo̊, což je bezesporu validní (př́ijmy podstatné části učitelů PF UK nedosahují pražského průměru), po mém soudu to však nebude důvodem jediným. Potřeba různorodé seberealizace může vést ke stř́íání kariér, kdy se během profesního života postupně věnujeme různým činnostem, anebo právě ke zmiňovaným souběhům. 
způsobilý přebít nap̌r. i mezinárodním společenstvím garantované ústavní uspořádání jsoucí výsledkem zhodnocení prríčin a výsledků občanské války, jak se ukázalo př́i rozhodování Evropského soudu pro lidská práva o „diskriminačním“ rázu „daytonské ústavy“ Bosny a Hercegoviny. V mezinárodních vztazích mohou být titulem k ingerenci do vnitřních záležitostí, protože lidská prrirozenost, s níž se tu operuje, nemůže být odlišná podle teritoria.

Patrným úskalím této dominance je př́lišné soustředění se na jednotlivce na úkor komunitární perspektivy, tedy oslabování významu přisuzovaného veřejnému zájmu a lidské pospolitosti jako něčemu trochu nebezpečnému, vyspekulovanému, samozřejmému, jak se komu líbí. Důsledkem je hledání základních práv státu, aby vůbec stát mohl být v určitých soudních sporech vzat v potaz.

Nicméně i v rámci lidskoprávního diskursu se mění akcenty. A nejde jen o vertikální nebo horizontální účinek lidských páv. Zatímco původní étos základních lidských práv byl spojen s omezováním veřejné moci v zájmu zachování svobody jako sféry individuální autonomie, nástupem antidiskriminační politiky se to mění. Vynucování nediskriminační rovnosti představuje pozvánku a pobídku pro veřejnou moc, aby vstupovala do sféry individuální autonomie osoby A (negativní svoboda) za účelem realizace životních cílů osoby B (pozitivní svoboda). V této optice není podstatná garance prostoru nezasahování státu, není-li zřejmé, co si s oním prostorem počít, tedy: ne svoboden, ale k čemu svoboden? 'Tím se ovšem proměňuje původní filosofický kontext lidských práv z liberalismu klasického směrem k soudobému liberalismu americkému, který je v lecčems více rovnostářský než socialismus: tomu šlo o ekonomický status, zatímco dnes jsou v centru pozornosti nejrůznější identity a směsice praktik současně směřujících k jejich vyrovnání i stvrzení.

S pěstováním a ochranou rozličných identit je začasté spojeno očekávání, že je bude veřejná moc nejen ctít, nýbrž bude dbát, aby byly ctěny jinými ve jménu důstojnosti dotčených. Nedostatek úcty může být snadno vnímán jako atak, výraz nenávisti (co vše je „hate speech“?), zdroj emocionální újmy. Jenže zatímco cílený, agresivní a hrubý útok na něčí atributy (slabiny?) můžeme považovat za neslušný či jinak nepřijatelný, bránit třeba jen mimoděčným poznámkám, jimiž se někdo (žena, muž, gay, bezvěrec, muslim...) může cítit dotčen, by znamenalo efektivní podvázání svobody projevu. Také likvidaci humoru.

Výsledkem tlaku na všemožná práva, a možná ještě spíše rychlosti, s níž se objevují a jsou prosazována, však může být ztráta autority práva (jsou tu odpovídající povinnosti, ztotožňujeme se s tím, co má jako právo platit, nebude takové právo ignorováno?) a zejména regres. Nemálo komentátorů přece upozorňuje, že brexit nebo nástup D. Trumpa souvisí s pocitem nemalé části populace, že nesmí dávat legitimně najevo, co si myslí, resp. co považuje za správné, jelikož „elity“ to něco označily za objektivně nesprávné. Rychlost a intenzita změn otřásly identitou domnělých „lidí včerejška“. Zde se sluší 
připomenout, že S. Huntington, tak kritizovaný H.-B. Lévym, reaktivní „nativistický“ rasismus neprrivolával, naopak se jej obával kvůli ohrožení podoby soužití, již už bylo dosaženo. ${ }^{35}$ Mají-li takto kaceřovaní nositelé nesprávných názorů možnost dát najevo nesouhlas s celkovou atmosférou společnosti, v níž je jim žíti, udělají to. Ale nebudou v takovém případě radikálnějšími odmítači novot, než by museli být? Není tudíž někdy méně více?

Z toho samozřejmě neplyne, že se nemáme pokoušet zlepšovat svět, v němž žijeme. Je to však lepší činit prostředky politickými, protože ty předpokládají širší participaci a souhlas, čímž tlačí rovněž na edukaci a přesvědčování širších vrstev společnosti. Zachovává se tak autonomie „chtění“. Právní cesta, tedy rozhodnutí soudu, je založena na tom, že už něco nějak je (dominance ,poznávání‘), a to je pro mnohé velice iritující, protože na to nemají (a neměli) vliv. Žijí pod vládou poručníků, nadto poručníků relativně málo citlivých, kteří se nepokoušejí posouvat celou společnost přiměřeným tempem, nýbrž postupovat metodou skoků. Ve skoku se však může společnost snadno roztrhnout, vůdce - poručník ztratí kontakt s podstatnou částí vedených, čímž přestane být jejich vưdcem: nemůže být následován, zmizel-li za horizontem. Místo zahrnutí všech do společenských dobrodiní zvyšujeme závaznou (mám právo) lat'ku toho, co tím dobrodiním je. Weberovská etika smýšlení (svědomî) vítězí nad etikou odpovědnosti, naplňování ideálu v maximální míře upozad’uje soudržnost společnosti.

Pozorovat ovšem můžeme náznaky zřetelnějšího návratu zájmu o uspořádání veřejné moci. Ch. Möllers koneckonců správně uvádí, že všechny problémy státního práva nelze vykládat přes práva základní. ${ }^{36} \mathrm{Na}$ poli politické teorie požaduje J. Waldron návrat k institucím, neb se mu zdá, že právě nastavení institucí bylo původní garancí svobody. Místo toho se politická teorie nechala pohltit rovností, svobodou a spravedlností, tedy v zásadě lidskoprávní perspektivou. ${ }^{37}$ Vedle neutuchajícího zájmu o soudy se tak už dříve objevily knihy o parlamentech, volící různé neotřelé způsoby jejich zkoumání, ${ }^{38}$ je tu řada titulů o komparatistice a právních transplantátech, ústavním designu, často spojených se jménem T. Ginburga, atd. Soustavnější pozornost je věnována víceúrovňovému vládnutí a v jeho rámci dělbě moci, legitimitě, ústavnímu pluralismu apod. Do ústavního práva mají přesah reflexe stavu současných demokracií, at’ už ve vztahu k referendům nebo třeba politickým stranám.

35 LÉVY, B.-H., op. cit., s. 248.

36 MÖLLERS, Ch., op. cit., s. 59.

37 WALDRON, J. Political Political Theory. Essays on Institutions. Cambridge, Massachussets: Harvard University Press, 2016.

38 BAUMAN, R. a T. KAHANA. The Least Examined Branch. The Role of Legislatures in the Constitutional State. Cambridge - New York: Cambridge University Press, 2006. V našich poměrech je takovým neotřelým způsobem typologie a analýza parlamentní kultury - srov. WINTR, J. Česká parlamentní kultura. Praha: Auditorium, 2010. Pro nauku ústavního práva je důležité vědět, jakými vlastně pravidly se parlamenty ř́dí, jaké vlivy na poslance působí. 
Byla-li řeč o soudech, určitě zůstávají ve sféře organického ústavního práva zásadním objektem výzkumu. Svědči jim řečený důraz na lidská práva, o nichž se rozhoduje spíše před soudy než v parlamentech, ale nejen to. Jde tu totiž jak o klasické (subsumpční) rozhodování o porušení lidských práv, tak o kreativní rozhodování o jejich (nečekaném) rozsahu, které sice je založeno na „chtěni" (co vše má v rámci práva na rodinný život obnášet sloučení rodiny?), legitimizuje se však kognitivně - jako rozpoznané právo. Snad by se tu dalo dovolávat non-sekvencionalismu po vzoru V. Cepla, který s oblibou užíval obratu „non sequitur" pro označení stavu, kdy něco nevyplývá z něčeho jiného, jakkoliv se to tváří opačně. ${ }^{39}$ Či přesněji, vyplývat může, chceme-li to, jde však o projev vůle, nikoliv intelektu. A to je důvodem, proč je ten druhý typ rozhodování o lidských právech problematický: implicitně jím dochází ke konstitucionalizaci něčeho, co by podle politických mocí konstitucionalizováno být nemělo (např̀. stejnopohlavní sňatky: mưže je táž ústava nezměněným textem zakazovat i zakazovat jejich zákaz jen kvưli posunu posuzování textu v čase?). Tím se oslabuje politický proces jako proces kolektivního sebe-určení coby opaku cizí dominance..$^{40}$ Ochrana lidských práv politickými prostředky přitom vcelku uspokojivě fungovala v prostředí demokracií westminsterského typu, neřeší však jednak problém „neviditelných menšin“, ${ }^{41}$ jednak klade vyšší nároky na politickou kulturu, stav občanského vzdělávání atd.

Jak je patrno, kreativní rozhodování soudů obnáší dotváření, případně i vytváření pravidel, tedy činnost odlišnou od aplikace předem daných pravidel. Ve shora podaném významu je taková činnost činností politickou, a to z hlediska své povahy, nikoliv kvůli tématu. Identifikace politického tématu více souvisí s politickými otázkami. ${ }^{42}$ Tady může být jasně založena kompetence soudů, referenční normy přezkumu nevyvolávají větší pochybnosti, přesto jde o téma s vysokou mírou citlivosti (volební proces, rozhodování o výjimečných stavech, rozhodování o státním rozpočtu atd.). I když se smiřujeme s oběma typy s politikou souvisejícího angažmá soudů a soudců, obvykle právě zde mluvíme o zdrženlivosti a sebe-omezení. Souvisí to se slovy M. Houellebecqua, ač vyslovenými na adresu univerzitních učitelů: „Naopak mě zarazila netečnost mých kolegů. Jako by si nic neprïpoustèli, nijak se jüch

39 Např. CEPL, V. Co je nejdůležitější. In: KYSELA, J. Deset let Ústavy České republiky: východiska, stav, perspektivy. Praha: Eurolex Bohemia, 2003, s. 70.

40 Ve vztahu k referendu srov. WINTR, J. a D. ASKARI. Lidská práva a rozhodování v referendu. Právník, roč. 2016, č. 2; vesměs se shodneme, že o lidských právech by se v referendu rozhodovat nemělo, ale co vše jsou lidská práva? Obvykle nám navíc nevadí, když je referendem príiata ústava, v níž se lidskoprávní katalog nachází.

$41 \mathrm{~K}$ tomu srov. ONDŘEJKOVÁ, J. Ochrana menšin zranitelných v rámci demokratické normotvorby. Jurisprudence, roč. 2015, č. 1.

42 Zdá se však, že politické otázky mohou být definovány nejen tématem (viz dále $\mathrm{v}$ textu), ale i povahou vyžadovaného rozhodnutí. Nejvyšší soud USA tak v př́padu Baker v. Carr z roku 1962 politickou otázku vztáhl na nedostatečnost standardů potřebných pro soudní rozhodnutí, nemožnost rozhodnout bez předchozí politické determinace nesoudcovským způsobem či nemožnost rozhodnout bez vyjádření nedostatku respektu k politickým mocím. Srov. UITZ, R. Constitutional Courts in Central and Eastern Europe: What Makes a Question Too Political? Iuridica International, 2007, č. 2. 
to netýkalo. Jen se poturzovalo, co jsem si myslel už roky: těm, kdo dosáhnou statusu vysokoškolského pedagoga, by ani nepríslo na mysl, že by jejich kariéru mobl politický vývoj nèjak ovlivnit. Cítili se naprosto nedotknutelni. “43 Snadno totiž za pedagogy, kteří u nás mají jen jistotu, že každá vláda prohlásí vzdělávání za svou prioritu, dosadíme soudce: pokud je jejich kariéra tak zajištěna před politickými vlivy (právní režim platů aj.), měli by do politického hájemství zasahovat uměřeně. Připouštím ovšem, že má perspektiva psaní od zeleného stolu může být značně odlišná od perspektivy soudce s konkrétní kauzou, konkrétními lidmi.

Velké téma rozsahu a intenzity soudního přezkumu (poslední slovo soudců, střežení průchodnosti kanálů politické komunikace, postih excesů, exempce...) je v základech koncepčního střetu právního a politického konstitucionalismu i debaty o současném demokratickém právním státě jako smíšené vládě svého druhu. ${ }^{44} \mathrm{Na}$ Slovensku patří k čilé literární diskusi o materiálním jádru tamní ústavy a jeho garancích. Soudy jako protivětšinové instituce evokují rovněž téma strachu z většiny (viz už výše), ${ }^{45}$ jež se promítá i v něčem, co bývá označováno jako konstitucionalismus strachu.

O konstitucionalismu strachu píše A. Sajó, ${ }^{46}$ není však sám. Řadí k němu v různé míre jak T. Hobbese se strachem ze smrti a vlastně i lidí, tak i tvůrce amerických a francouzských ústavních dokumentů ze sklonku 18. století. Na ně působil strach z tyrana (silné exekutivy) i strach z nemohoucnosti veřejné moci, strach z povstání i konkrétních násilníků na pařížských ulicích a francouzském venkově. V širším smyslu sem spadá rovněž „vybojovávání minulých válek“ př̀i vzniku a změnách ústav - reflexe (strach z) minulých selhání ve snaze se jim naprŕšště vyhnout. To se nemusí týkat jen konkrétních institutů a institucí v podobě patrné při tvorbě německého Základního zákona (oslabení prezidenta a prvků přímé demokracie, stabilizace vlád), ústavy francouzské Páté republiky (zásadní reforma systému směrem k posílení exekutivy) nebo naší Ústavy (zkušenost se symetrickým bikameralismem Federálního shromáždění nebo substituční rolí předsednictev zákonodárných sborů). M. Kriele ukazuje, jak chaos občanské války vede k etablování suverénního státu, potřeba limitace jeho moci ke vzniku státu ústavního, zkušenost s jeho slučitelností např. s otroctvím k demokratickému a sociálnímu ústavnímu státu, jenž tak je odpovědí na opakovaná a různorodá volání po spravedlnosti. ${ }^{47}$

43 HOUELleBECQ, M. Podvolení. Praha: Odeon, 2015, s. 61.

44 MANIN, B. The Principles of Representative Government. Cambridge University Press, 1997, s. 238; ONDŘEJKOVÁ, J. Smíšená forma vlády a Evropská unie. Právník, roč. 2010, č. 7.

45 Protivětšinovými institucemi jsou soudy jen v určitém smyslu. Zásadně totiž slouží většině, jež stojí za zákony, které soudy aplikují. Důrazem na zákon však omezují momentální většinu na ulici či v průzkumech veřejného mínění. Obvyklejší je však na soudy nahlížet jako na protivětšinové instituce v jejich roli ochránců ústavy i proti formalizované, avšak početně nekvalifikované většině, prípadně i proti většině kvalifikované, jde-li o klauzule věčnosti, nadpozitivní principy, přirozená práva apod.

46 Zvláště SAJÓ, A. Constitutional Sentiments. New Haven - London: Yale University Press, 2011.

47 KRIELE, M. Einführung in die Staatslehre. Die geschichtlichen Legitimitätsgrundlagen des demokratischen Verfassungsstaates. 6. vyd. Stuttgart - Berlin - Köln: Kohlhammer, 2003. 
Jinou silnou emocí je stud, který spoluutváří status lidských práv: stud za to, co bylo možné a běžné a nemělo by se to vrátit (otroctvî), pročež vytváríme náležité pojistky. Právě se studem je však třeba nakládat citlivě, protože má velký potenciál zvrátit se ve vzdor: máme-li stydět i za to, že jsme muži, bílí, ze střední třídy (bílí anglosaští protestanti /WASP/ v USA), může to vést nikoliv ke korekci excesů plynoucích z naznačených identit, ale naopak k jejich vehementnímu prožívání a prosazování.

Lidí se sice bojíme, současně jim však - ne tak docela paradoxně - musíme i důvěřovat, protože na jejich součinnost jsme odkázání, v politickém provozu rozhodují spolu s námi (volby, referendum), ba i místo nás (reprezentativní instituce). ${ }^{48}$ Bez dưvěry nemůže úspěšně působit stát ani demokratický ani právní: $v$ jednom př́ípadě by se smazával rozdíl oproti demokratickým formám vládnutí (vládne nám někdo jiný, cizí, od nás odlišný), v př́ípadě druhém by byla vláda nestranných pravidel transformována ve svévoli. Patř́ to do záběru nauky ústavního práva? Je-li spojena s ústavní teorií, pak jistě ano.

Zdá se mi, že nauka ústavního práva je specifická ještě v jednom ohledu. Nejen otevřeností vưči jiným oborům ve své poznávací kapacitě (co jako právo platí, jak vzniká, jak se uplatňuje...), ale i svébytným posláním na poli výchovy k občanství a demokracii. Po staletí nikdo nepochyboval o tom, že budoucího vládce je třeba na jeho roli připravovat. Vládnou-li občané, lid, my, mělo by něco podobného být zbytečným?

Nauka ústavního práva může a má být také mediátorem hodnot, na nichž spočívá ten který ústavní řád, má zprostředkovat porozumění vztahů mezi nimi a konkrétním ústavním designem (institucemi v nejširším slova smyslu), a tím přispívat k upevnění systému a inkluzi do něj. Zapojovat se tak mưže do šířnení široce pojímané právní a sociálněvědní gramotnosti. ${ }^{49}$ Ukazuje se totiž, že dlouhodobě uspěje jen ten ústavní řád, jenž je svými občany vnímán jako řád dobrého vládnutí, v němž nemusejí rozhodovat o všem, protože mají důvěru v to, že se rozhoduje poučeně, citlivě, se zřetelem k obecnému zájmu, $\mathrm{v}$ němž je zahrnut rovněž jejich zájem vlastní.

Alternativou inkluze je vytěsnění, tedy exkluze, jîž se z mnohých subjektů stávají objekty systému. V takovém modelu žilo lidstvo po většinu svých dějin a i dnes je vcelku evidentní, že co do individuálních vyhlídek různého typu není subjekt jako subjekt. Model to může být funkční, jsou-li ti vytěsnění apatičtí a neorganizovaní, tj. neaktivujî se jako nepráatelé systému. Př́padně mohou být aktivní, ale pak jich musí být natolik málo, aby je systém potlačil, izoloval, zprofanoval před apatiky, které se pokoušejí burcovat. Na to se však jednak nedá spoléhat, jednak je demokracie založena na myšlenkách rovnosti a participace, jež značí právě inkluzi.

48 URBAN, M. Komu důvěřujeme ve stále složitějším světě? Acta Universitatis Carolinae Iuridica, roč. 2014, Č. 1.

49 FRIEDEL, T. a T. KRUPOVÁ. Sociálněvědní gramotnost - role akademika při zvyšování vzdělanosti. Acta Universitatis Carolinae Iuridica, roč. 2014, č. 1. 